\title{
Distinct expression, localization and function of two Rab7 proteins encoded by paralogous genes in a free-living model eukaryote
}

\author{
Magdalena Osińska, Jolanta Wiejak, Emilia Wypych, Henryk Bilski, Rafał Bartosiewicz and \\ Elżbieta Wyroba
}

Nencki Institute of Experimental Biology, Warszawa, Poland

Rab7 GTPases are involved in membrane trafficking in the late endosomal/lysosomal pathway. In Paramecium octaurelia Rab7a and Rab7b are encoded by paralogous genes. Antipeptide antibodies generated against divergent C-termini recognize Rab7a of 22.5 $\mathrm{kDa}$ and Rab7b of $25 \mathrm{kDa}$, respectively. In 2D gel electrophoresis two immunoreactive spots were identified for Rab7b at pl about 6.34 and about 6.18 and only one spot for Rab7a of pl about 6.34 suggesting posttranslational modification of Rab7b. Mass spectrometry revealed eight identical phosphorylated residues in the both proteins. ProQ Emerald staining and ConA overlay of immunoprecipitated Rab7b indicated its putative glycosylation that was further supported by a faster electrophoretic mobility of this protein upon deglycosylation. Such a post-translational modification and substitution of Ala ${ }^{140}$ in Rab7a for Ser ${ }^{140}$ in Rab7b may result in distinct targeting to the oral apparatus where Rab7b associates with the microtubular structures as revealed by STED confocal and electron microscopy. Rab7a was mapped to phagosomal compartment. Absolute qReal-Time PCR analysis revealed that expression of Rab7a was 2.6-fold higher than that of Rab7b. Upon latex internalization it was further 2-fold increased for Rab7a and only slightly for Rab7b. Post-transcriptional gene silencing of rab7a suppressed phagosome formation by $70 \%$ and impaired their acidification. Ultrastructural analysis with double immunogold labeling revealed that this effect was due to the lack of V-ATPase recruitment to phagolysosomes. No significant phenotype changes were noticed in cells upon $r a b 7 b$ silencing. In conclusion, Rab7b acquired a new function, whereas Rab7a can be assigned to the phagolysosomal pathway.

Keywords: Rab7 isotypes, RNAi, 2D electrophoresis, antipeptide antibodies, Real-Time PCR, glycosylation, STED, Paramecium octaurelia

Received: 27 May, 2011; revised: 27 August, 2011; accepted: 06 October, 2011; available on-line: 27 October, 2011

\section{INTRODUCTION}

Rab7 GTPase mediates trafficking from early to late endosomes and from late endosomes to lysosomes (Zerial \& McBride, 2001; Pfeffer \& Aivazian, 2004; Stenmark, 2009). It plays a crucial role in phagosome maturation in many cell types (Rupper et al., 2001; Vieira et al., 2002; Kinchen \& Ravichandran, 2008) and in endocytic organelle maintenance (Vanlandingham \& Ceresa, 2009), especially lysosome biogenesis (Bucci et al., 2000).
Our studies on phylogeny and evolution of Rab7 proteins indicate that these GTPases evolved before radiation of main eukaryotic supergroups and that gene duplication occurred in this subfamily giving rise to their several copies - among others — in some representatives of excavates, ciliates and amoebozoans (Mackiewicz \& Wyroba, 2009).

A great expansion of Rab proteins is correlated with development of the endomembrane system contributing to functional specialization and complexity of subcellular trafficking characteristic for eukaryote evolution Jekely, 2007; Dacks et al., 2008; Brighouse et al., 2010; Elias, 2010). Interestingly, the individual Rab copies show substantially different expression levels. One of the model cells to study this problem is Paramecium octaurelia in which paralogous genes rab7a and rab7b encode Rab7 isotypes (Surmacz et al., 2006). Previously, we have shown in this cell the association of Rab7 with the phagosomal compartment with the usage of anti-human Rab7b antibody that was not discriminating the two Paramecium Rab7 isotypes (Surmacz et al., 2003; Wyroba et al., 2007). The overall predicted protein sequences of $P$. octaurelia Rab7 isotypes that were cloned by us are more similar to the mammalian counterparts than to Rab7 deriving from some parasitic protozoa that emerged earlier in evolution (Surmacz et al., 2006). In the amino acid sequences of $P$. octaurelia Rab7 proteins four out of the total five amino acid substitutions map to a hypervariable domain (HVD) that contains RabSF4 motif and shows the highest level of sequence divergence among the Rab GTPases, contributing to specific targeting and functions of these proteins (Ali \& Seabra, 2005). To elucidate the role and localization of the P. octaurelia Rab7 isotypes peptide antibodies were generated to this region as a specific tool. The presence of individual Rab7 proteins was revealed by immunoblotting, two-dimensional gel electrophoresis, proteomic analysis, immunofluorescence in confocal/STED mode and ultrastructural studies. Gene silencing of rab7 genes was performed and the expression of the isotypes was evaluated both at the mRNA and protein level.

The unexpected differences found in expression, localization and function of Rab7a and Rab7b are discussed in terms of structural determinants and putative posttranslational modifications. These studies contribute to a

e-mail e.wyroba@nencki.gov.pl

Abbreviations: Abs, antibodies; LC-MS, liquid chromatographymass spectrometry; RNAi, RNA interference; STED, stimulated emission depletion microscopy. 
challenging task of elucidation whether protein products of paralogous genes acquired new function.

These approaches enabled obtaining novel data on localization, interaction and function of Rab proteins in a free-living single-celled Eukaryote.

\section{MATERIALS AND METHODS}

All chemicals were from Sigma Aldrich Chemie $\mathrm{GmbH}$ (Steinheim, Germany) unless noted otherwise.

Cells. Paramecium octaurelia cells (stock 299s), 5-day-old axenic cultures were harvested as in Wyroba et al. (2007).

RT PCR and Real Time PCR. Total RNA was obtained using SV Total RNA Isolation System (Promega Corporation, Madison, USA) as recommended by manufacturer and RNA concentration and purity was determined by spectrophotometer readings at 260 and 280 $\mathrm{nm}$. One $\mu \mathrm{g}$ of RNA was reverse transcribed using AMV Reverse Transcriptase (Promega).

The RT-PCR was carried out for 30 cycles $(30 \mathrm{~s}$ at $94^{\circ} \mathrm{C}, 52^{\circ} \mathrm{C}$ for $30 \mathrm{~s}, 1 \mathrm{~min}$ at $72^{\circ} \mathrm{C}$ ) with final extension at $72^{\circ} \mathrm{C}$ for $10 \mathrm{~min}$ in a PTC-200 DNA Engine (MJ Research, Inc., Watertown, USA). The following primers were used: for rab7a (AY744503 Paramecium octaurelia) forward 5'-ATGGCCAGCCAGAAGAAGCAA and backward 5'-ACAACATCCTCCT'TATT'TGGCTTATGGT'T'TTGGCTC, and for rab7b (AY644723 Paramecium octaurelia): forward 5'-ATGGCCAGCCAGAAGAAGCAA and backward 5'-ACAACATCCTCCTTATTTGGTCTATTTCT'TTGGGTCT. Glyceraldehyde3-phosphate dehydrogenase (GAPDH) gene was used as an intrinsic control of mRNA quantity and primers were: forward 5'-ACCAGTGACCGTAAAAGCTA and backward 5'-GATGGAGCAGACATAATGA designed according to $P$. tetraurelia GAPDH sequence (AF319452). Amplification products were analyzed with an InGenius camera (Syngene, Cambridge, UK).

Real-time RT-PCR was performed using an ABI Prism 7500 Sequence Detection System (Applied Biosystems, Foster City, USA). For absolute quantification cDNA samples $\left(4 \times 10 \mathrm{pg}\right.$ to $\left.4 \times 10^{-4} \mathrm{pg}\right)$ of $\mathrm{rab} 7 \mathrm{a}$ and $\mathrm{rab} 7 \mathrm{~b}$ were amplified in triplicate for both target genes to create a standard curve. Likewise, $1 \mu \mathrm{l}$ of cDNA was amplified in triplicate for $r a b 7 a$ and $r a b 7 b$ mRNA. Each sample supplemented with the primers was made up to 15 $\mu l$ with SYBR Green PCR Master Mix (Applied Biosystems). The following primer pairs were used: 5'-TCAAGACATTGCAAAGGCT and 5'-CT'TATGGT'T'TTGGCTC specific for mRNA of rab7a and 5'-AGCT'TTCCAAGACAT'TGCA and 5'-GGTCTATTTCT'T'TGGGTCT specific for mRNA of rab7b. mRNA levels were quantified using the critical threshold $(\mathrm{Ct})$ value. Relative gene expression during phagocytosis was analyzed using the $\Delta \Delta \mathrm{Ct}$ method (Winer et al., 1999) where mRNA level of rab7a and rab7b in control cells was set to $100 \%$. To compensate for variations in RNA input and efficiency of reverse transcription, GAPDH mRNA was quantified using primers: 5'-T'TAACACAGT'T'TGTGAATC and 5'-GATGGAGCAGACATAATGA and the results were normalized to these values. Amplification of specific transcripts was further confirmed by obtaining melting curve profiles. Controls with no template were performed with each assay.

Fractionation and SDS/PAGE. Cell suspension was immediately immersed in ice-chilled homogenization buffer (HB: 0.05 M Tris/HCl, 0.01 M EDTA, pH 7.4) containing protease/phosphatase inhibitors cocktail (Ro- che, Mannheim, Germany) and cleared by centrifugation (twice for $5 \mathrm{~min}$ at $12000 \times \mathrm{g}$ at $4^{\circ} \mathrm{C}$ ) yielding homogenate $(\mathrm{H})$. Alternatively, $1 \%$ Triton $\mathrm{X}-100$ was added to $\mathrm{HB}$ (yielding $\mathrm{H} / \mathrm{T}$ ). Protein samples were denaturated, subjected to electrophoresis on $15 \%$ SDS polyacrylamide gels (PAGE) and stained with silver/Brilliant Blue $G$ or blotted onto nitrocellulose or polyvinylidene difluoride (PVDF) membrane by wet transfer.

Immunoblotting. Immunoblotting was performed as in Wiejak et al. (2004). The primary Abs specific for Paramecium octaurelia Rab7 GTPases were raised against the synthetic peptides corresponding to the amino acid sequence of the cloned Rab7a (AAL08054): ${ }^{191}$ LTKQSQKPQAKQGGC 205 (in guinea pig) or Rab7b (AAW68046): ${ }^{191}$ LTKQDPKKQTKQGGC ${ }^{205}$ (in rabbit), respectively, mapping to their variable C-terminal regions, with an additional cysteine preceding the above sequences. Peptide synthesis and immunization were done by Genosphere Biotechnologies (Paris, France). GAPDH was a control of equal loading in quantitative analysis as detected with $\mathrm{Ab}$ from Chemicon (Millipore, Billerica, USA). Following incubation with appropriate secondary horseradish peroxidase (HRP)-conjugated $\mathrm{Ab}(2 \mathrm{~h}, \mathrm{RT})$, blots were washed and subjected to SuperSignal WestPico chemiluminescent detection system (Pierce, Rockford, USA). Protein bands were quantified by GeneTools software (Syngene, Cambridge, UK). Omitting of primary Abs produced no bands.

Proteomic analysis. Silver or Brilliant Blue G stained protein bands corresponding to those cross-reacting with anti-Rab7a or anti-Rab7b were cut off from the gel and incubated after rehydratation in a digestion solution (12.5 $\mu \mathrm{g} / \mathrm{ml}$ of trypsin (Promega; Trypsin Gold, MS Grade) or $0.4 \mathrm{nmol} / \mathrm{ml}$ of Endoproteinase Asp-N (from Pseudomonas fragi mutant strain for protein sequencing, EC 3.4.24.33) in $50 \mathrm{mM} \mathrm{NH}_{4} \mathrm{HCO}_{3}$ ) for $45 \mathrm{~min}$ at $4^{\circ} \mathrm{C}$. Excess liquid was removed and gel pieces were incubated for at least $18 \mathrm{~h}$ in $50 \mathrm{mM} \mathrm{NH} \mathrm{HCO}_{3}$ at $37^{\circ} \mathrm{C}$. Further processing of the samples and nano liquid chromatography-mass spectrometry (LC-MS/MS) analysis were performed as described in Bierczynska-Krzysik et al. (2006). During analysis, the most intense peaks in the range of 400-1400 m/z. were automatically fragmented by means of data-dependent fragmentation as described in Noga et al. (2005).

The spectra acquired from each analysis were processed using Bruker's Data Analysis software. Protein identification was made using MASCOT ver. 1.9 search engine against the Swiss-Prot and TrEMBL sequence database as well as a database containing only Paramecium $\mathrm{Rab}$ protein sequences. Search parameters were set as follows: taxonomy: all, enzymes: as above, with up to one missed cleavage, fixed modifications: carbamidomethyl, variable modifications: methionine oxidation, peptide mass: monoisotopic with tolerance: $0.8 \mathrm{Da}$, fragment mass tolerance: $0.5 \mathrm{Da}$, possible peptide charges: $1+, 2+$ and $3+$, the instrument: ESI-TRAP. The whole procedure was carried out at the Neurobiochemistry Department of the Faculty of Chemistry, Jagiellonian University, Cracow, Poland.

Glycoprotein detection. Three types of experiments were performed:

1. Detection with Pro-Q Emerald 300 Glycoprotein Gel and Blot Stain Kit (Molecular Probes, Eugene, USA) as described in Wyroba et al. (2007).

2. Concanavalin A overlay assay.

Presence of sugar side-chains on proteins was detected with Con A labeled with peroxidase (Gunther et 
al., 1973). Blots, after blocking with phosphate buffered saline (PBS)/Tween $20(2 \% \mathrm{v} / \mathrm{v})$ for $2 \mathrm{~min}$ followed by two rinses in PBS, were incubated with $4 \mu \mathrm{g} / \mathrm{ml}$ of lectin-peroxidase in PBS containing $0.05 \%(\mathrm{v} / \mathrm{v})$ Tween 20, $1 \mathrm{mM} \mathrm{CaCl}_{2}, 1 \mathrm{mM} \mathrm{MnCl}$ and $1 \mathrm{mM} \mathrm{MgCl}_{2}$ for $16 \mathrm{~h}$ at $\mathrm{RT}$ and rinsed in PBS.

3. PNGase F (N-Glycosidase F) digestion of homogenate as in Wyroba et al. (2007).

Digestion with alkaline phosphatase. Aliquots of cell homogenate were digested with alkaline phosphatase (1 U enzyme $/ 20 \mu \mathrm{g}$ of protein) diluted in buffer containing: $10 \mathrm{mM}$ Tris/ $\mathrm{HCl}, \mathrm{pH} 8.0,5 \mathrm{mM} \mathrm{MgCl}, 0.2 \mathrm{mM}$ $\mathrm{ZnCl}_{2}$ for $2.5 \mathrm{~h}$ at $37^{\circ} \mathrm{C}$. Then probes were denaturated and separated by SDS/PAGE.

2D gel electrophoresis. Isoelectric focusing of cell homogenate pre-cleared with ReadyPrep 2-D Cleanup Kit (Bio-Rad Laboratories, Berkeley, USA) was carried out on 7-cm immobilized $\mathrm{pH}$ gradient strips $(4-7 \mathrm{pH}$ gradient) that were rehydrated for $16 \mathrm{~h}$. Focusing was performed at $20^{\circ} \mathrm{C}$ for $8-10000 \mathrm{~V}$-h at a maximum of $4000 \mathrm{~V}$ in a Protean IEF Cell (Bio-Rad Laboratories). The strips were incubated in the 1 st $(6 \mathrm{M}$ urea, $0.375 \mathrm{M}$ Tris/ $\mathrm{HCl}, \mathrm{pH} 8.8,2 \%$ SDS, 20\% glycerol, 2.5\% (w/v) dithiothreitol) and 2nd equilibration solutions (6 M urea, $0.375 \mathrm{M}$ Tris $/ \mathrm{HCl}, \mathrm{pH} 8.8,2 \%$ SDS, $20 \%$ glycerol, $2.5 \%(\mathrm{w} / \mathrm{v})$ iodoacetamide) for $10 \mathrm{~min}$ each. The second dimension was run on $15 \%$ SDS/PAGE and gels were stained with either silver/Brilliant Blue $G$ or analyzed by immunoblotting.

Immunoprecipitation. Aliquots of cell homogenate (0.8-1 mg of total protein) in an ice-chilled HB were precleared with Protein A Sepharose CL-4B (GE Healthcare, Uppsala, Sweden) for $1.5 \mathrm{~h}$ at $4^{\circ} \mathrm{C}$, centrifuged for $2 \mathrm{~min}\left(12000 \times g, 4^{\circ} \mathrm{C}\right)$ and supernatants incubated with specific $\mathrm{Ab}(1: 50-1: 100)$ for $2 \mathrm{~h}$ at $4^{\circ} \mathrm{C}$. Then, $70 \mu \mathrm{l}$ of Protein A Sepharose (prewashed with HB) was added to each probe, incubated overnight $\left(4^{\circ} \mathrm{C}\right)$ and washed 6 times with $\mathrm{HB}$. Immunocomplexes were reduced by boiling in the presence of 5\% 2-mercaptoethanol.

Gene silencing by feeding. RNAi was performed by feeding Paramecium with Escherichia coli HT115 according to the procedure (Galvani \& Sperling, 2002) in the Paramecium database (http://paramecium.cgm.cnrs-gif. $\mathrm{fr} / \mathrm{RNAi}$ ). The entire open reading frame for Rab7a or Rab7b was subcloned into pL4440 (Addgene plasmid 1654) enabling double stranded RNA (dsRNA) synthesis (Timmons \& Fire, 1998). Ciliates fed with bacteria bearing empty plasmids were used as a control. Plasmid inserts were sequenced. Double silencing experiments were performed with mixes of bacterized media upon adjustment of optical density. Feeding was repeated every $24 \mathrm{~h}$ with freshly induced bacteria and the results of silencing were analyzed after $96 \mathrm{~h}$. Cell growth was unaffected during silencing experiments.

Confocal microscopy. Cells were fixed with $3.5 \%$ (w/v) freshly prepared formaldehyde $(15 \mathrm{~min})$ followed by triple washing with PBS and labeling with Abs against Rab7a and Rab7b. Anti-guinea pig conjugated with Cy5 (Jackson ImmunoResearch, Pennsylvania, USA) at 1:200 or anti-rabbit conjugated with FITC (1:50), respectively were used as secondary Abs. For tubulin localization monoclonal anti- $\alpha$-tubulin Ab $(1: 200)$ was used followed by anti-mouse conjugated with A647N (ATTO-TEC $\mathrm{GmbH}$, Siegen, Germany; 1:150). Samples were washed six times, mounted in 2.5\% 1,4-diazabicyclo [2.2.2] octane in Mounting Medium and analyzed in a Leica TCS SP2 and Leica TCS SP5 Spectral Confocal with stimulated emission depletion (STED) system (Leica Mikrosys- teme, Vienna, Austria). Series of single $0.2-\mu \mathrm{m}$ optical sections were collected. The image was scanned at high resolution (63× oil objective, $1.32 \mathrm{NA})$. A647N staining was visualized in STED mode (excitation pulses of 635 $\mathrm{nm}$ that were synchronously followed by STED pulses of $750 \mathrm{~nm}$, emission recorded in the range of 655-715 $\mathrm{nm})$.

Electron microscopy. Cells were fixed for $20 \mathrm{~min}$ at RT in 4\% paraformaldehyde- $0.2 \%$ glutaraldehyde in PBS and rinsed twice in PBS (10 min) followed by centrifugation. Samples were dehydrated in graded ethanols, embedded in LR White (Polysciences Europe GmbH, Eppelheim, Germany).

Ultrathin sections on formvar-coated nickel grids (Agar Scientific Ltd., Essex, UK) were exposed (overnight, RT) to custom-made Abs (described in 'Immunoblotting') or $\mathrm{Ab}$ against $\mathrm{H}$ subunit of $\mathrm{V}$-ATPase from Santa Cruz Biotechnology, Inc. This subunit is indispensable for the enzyme activity (Ho et al., 1993; Parra et al., 2000). Next, a 2-h incubation with respective secondary Abs conjugated to colloidal gold: anti-rabbit, anti-chicken or anti-guinea pig IgG (all from Jackson ImmunoResearch, West Grove, USA) was performed. Micrographs were taken with JEM $1200 \mathrm{EX}$ and JEM 1400 (JEOL Ltd., Tokyo, Japan) equipped with a digital camera (CCD MORADA; SiSOlympus, Münster, Germany). No immunolabeling was noticed when primary Abs were omitted.

Monitoring of phagocytic activity and phagosome acidification. Cells after 96 hours of silencing were centrifuged, washed, left for $1 \mathrm{~h}$ in sterile MSS solution (migration salt solution: Soldo et al., 1966) and divided into two aliquots: in one ciliates were fed with yeast prestained with Congo-Red (Fluka, Taufkirchen, Germany) to follow the acidification of phagosomes (Sehring et al., 2007), whereas in the second aliquot efficiency of phagocytic activity induced by latex beads $(0.77 \mu \mathrm{m}$, Serva Electrophoresis GmbH, Heidelberg, Germany; 100 -fold diluted) was monitored. The number of phagosomes in control cells was set as $100 \%$. In both cases evaluation of at least 20 cells per experiment, with three independent experiments per each type, was performed.

\section{RESULTS}

\section{Immunodetection of Rab 7 isotypes with specific peptide antibodies and proteomic analysis}

The specific antipeptide Abs generated against the C-terminal amino acid stretch comprising four out of the total five amino acids that distinguish Rab7a from Rab7b recognized a distinct single immunoreactive band of $22.5 \mathrm{kDa}$ for Rab7a (Fig. 1B) and $25 \mathrm{kDa}$ for Rab7b (Fig. 1C) in cell homogenate subjected to SDS/PAGE electrophoresis (Fig. 1A). These experimental molecular weights (MW) are consistent with those observed for Rab GTPases in mammals (Brighouse et al., 2010), whereas the calculated MWs are almost the same for both the proteins: $23.2 \mathrm{kDa}$ for $\mathrm{Rab} 7 \mathrm{a}$ and $23.3 \mathrm{kDa}$ for Rab7b. In the presence of Triton X-100 Rab7b appeared more hydrophilic than Rab7a (Fig. 1B, C). 2D gel electrophoresis (Fig. 2A) followed by Western blot suggested that the lower electrophoretic mobility of Rab7b may be due to a post-translational modification — such as phosphorylation or glycosylation: two immunoreactive spots of slightly different $\mathrm{pI}(\sim 6.34$ and $\sim 6.18$, respectively $)$ and $M_{\mathrm{r}}$ were detected with anti-Rab7b Ab (Fig. 2B), whereas anti-Rab7a Ab revealed one spot of $\mathrm{pI} \sim 6.34$ (Fig. 2C). The pI values of these spots are similar to the calculated 
Table 1. Phosphorylated residues identified by LC-MS/MS in peptides matching both Rab7 proteins in Paramecium octaurelia.

\begin{tabular}{|c|c|}
\hline Asp-N endopeptidase & Trypsin \\
\hline${ }^{16}$ DSGVGKTSLMNQYVNARFTQQYRATVGA ${ }^{43}$ & ${ }^{39} \underline{\mathrm{ATVGADFMAK}^{48}}$ \\
\hline${ }^{63}$ DTAGQERFQSLGGAFYRGADCCVLVY ${ }^{88}$ & ${ }^{80} \underline{\text { GADCCVLVYDITNPK }}{ }^{94}$ \\
\hline${ }^{170} \underline{\text { DIAKAAASQEK }}{ }^{178}$ & ${ }^{159} \mathrm{DATNIEQAFQDIAK}^{172}$ \\
\hline \multicolumn{2}{|l|}{${ }^{180}$ DEEIFFPTTVTLTKQ ${ }^{194}$} \\
\hline 180DEEIFFPTTVTLTKQSQKPQAKQGGCC206 & \\
\hline
\end{tabular}

Paramecium cell homogenate was subjected to SDS/PAGE and bands corresponding to those recognized in Western blot analysis by anti-Rab7a or anti-Rab7b antibody, respectively, were digested with trypsin or Asp-N endopeptidase prior to proteomic analysis. All the obtained peptides were identical with the previously published amino acid sequence of these proteins (Surmacz et al., 2006). The same peptide fragments revealed in the probes derived from both the digests are underlined. Phosphorylated residues shown as bold.

pI value (according to: http://scansite.mit.edu/cgi-bin/calcpi) for Rab7a and Rab7b that was approx. 6.2 for both the proteins.

Liquid chromatography-tandem mass spectrometry revealed peptides matching the deduced amino acid sequences (Surmacz et al., 2006) of Rab7 isotypes in trypsin or Asp-N endopeptidase digests of the silver-stained

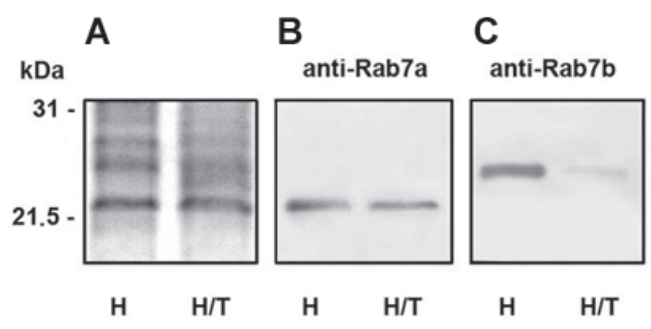

Figure 1. Identification of Rab7a and Rab7b isotypes in Paramecium octaurelia.

Specific antipeptide antibodies recognize in cell homogenate single immunoreactive bands of different electrophoretic mobility. Total cell homogenate obtained in absence $(\mathrm{H})$ or presence of Triton $\mathrm{X}-100(\mathrm{H} / \mathrm{T})$ was resolved by SDS/PAGE followed by Ponceau Red staining (A) and Western blot with the usage of anti-Rab7a (B) or anti-Rab7b antibody (C). The relative positions of molecular weight markers are indicated on the left.

A



Figure 2. Two-dimensional gel electrophoresis followed by immunodetection with specific Rab7 antipeptide antibodies. Representative gel showing cell homogenate separated according to charge (pl) by isoelectric focusing (IEF) in the first dimension and according to size by SDS/PAGE in the second dimension as described in Materials and Methods. Each 2D gel was loaded with an equal amount of total protein and prepared in duplicates: one was stained with colloidal Coomassie Blue $(\mathbf{A})$ and the second gel was probed with anti-Rab7a (C) or anti-Rab7b Abs (B). Please note two immunoreactive spots for Rab7b (B). protein bands corresponding to those observed in Western blot (Table 1). Proteolytic cleveage with the latter enzyme resulted in identification of longer peptides including${ }^{180}$ DEEIFFPTTVTLTKQSQKPQAKQGGCC $^{206}$ characteristic for Rab7a that contained all the four distinct amino acid residues not present in Rab7b (Table 1).

Moreover, mass spectrometry confirmed the presence of the essential switch regions (I and II) and Rab family motifs: RabF1: ${ }^{41}$ VGADFF; $^{45}$ RabF3: ${ }^{69}$ RFQSLG $^{74}$; RabF4: ${ }^{77}$ FYRGA ${ }^{81}$; RabF5: ${ }^{86}$ LVYDIT $^{91}$ as well as Rab subfamily motif RabSF2: ${ }^{23}$ SLMNQYVNARFTQQYRA ${ }^{39}$, RabSF4: ${ }^{176}$ SQEKDEEIFFPT'T ${ }^{188}$ that are important in interactions of Rab proteins with their effectors. The identified motifs show a high level of conservancy with those (Table 2) deriving from Metazoa (Mackiewicz \& Wyroba, 2009). These results illustrate also that the Abs generated are suitable tools to explore function and localization of Rab7a and Rab7b in this cell.

No significant difference was observed in the phosphorylation pattern for both isotypes as analyzed with Pro-Q Diamond that detects all phosphorylated residues and with Abs specific for phospho-serine, -threonine and -tyrosine (data not shown). A direct evidence of phos-

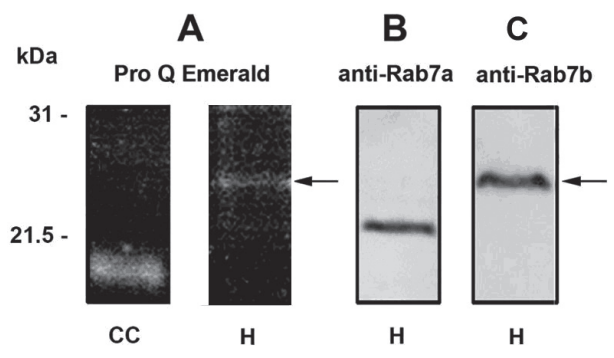

Figure 3. Detection of putative glycosylation of $P$. octaurelia Rab7 isotypes.

ProQ Emerald staining was performed $(\mathbf{A})$ on cell homogenate $(\mathrm{H})$ separated by SDS/PAGE (CC - Candy Cane, glycoprotein marker) and compared with the homogenate samples analyzed on the same gel and followed by immunoblotting for Rab7a (B) or Rab7b (C), respectively. The relative positions of molecular weight markers are indicated on the left. Arrows indicate glycosylated band corresponding to Rab7b.

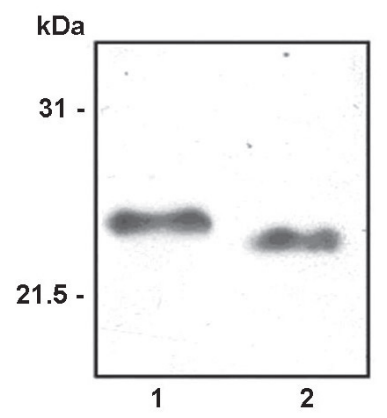

Figure 4. Effect of deglycosylation of Rab7b on its electrophoretic migration in SDS/PAGE.

Paramecium homogenate digested with PNGase F (lane 2) and the undigested homogenate serving as a control (lane 1) after SDS/PAGE separation were immunoblotted with anti-Rab7b antibody. The relative positions of molecular weight markers are indicated on the left. 
WB: anti-Rab7a

ConA

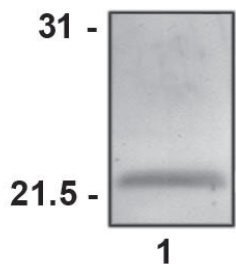

IP anti-Rab7a

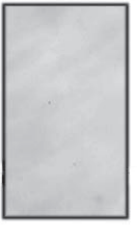

2

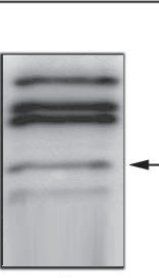

3
WB: anti-Rab7b

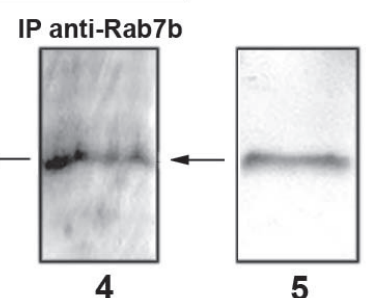

Figure 5. ConA overlay assay of immunoprecipitated Rab7a and Rab7b proteins.

Aliquots of cell homogenate (3) and homogenate immunoprecipitated with anti-Rab7a (2) or anti-Rab7b (4) were resolved by SDS/PAGE and followed by ConA overlay. Lanes 1 and 5 represent homogenate immunoblotted for Rab7a or Rab7b, respectively. Arrows indicate bands corresponding to Rab7b. Please note a lack of the glycosylated species corresponding to the immunoreactive band detected with anti-Rab7a specific antibody.

phorylation of both isotypes at the eight following residues was obtained by LC-MS/MS: $\mathrm{S}^{17}, \mathrm{~S}^{23}, \mathrm{~S}^{72}, \mathrm{~T}^{34}, \mathrm{~T}^{40}$, $\mathrm{T}^{64}, \mathrm{Y}^{78}$ and $\mathrm{Y}^{88}$ (Table 1). Digestion of cell homogenate with alkaline phosphatase that is routinely used to dephosphorylate proteins revealed no changes in electrophoretic migration pattern of both isotypes confirming that phosphorylation is not the cause of the differences in their mobility during SDS/PAGE (data not shown).

Potential glycosylation of Rab7 isotypes was investigated using ProQ Emerald reagent: a glycosylated band of $M_{\mathrm{r}}$ about $25 \mathrm{kDa}$ (Fig. 3A) corresponding to Rab7b was visualized in homogenate (Fig. 3C). No glycosylated species at $M_{\mathrm{r}}$ about $22.5 \mathrm{kDa}$ was observed (Fig. 3A, B). Moreover, digestion of cell homogenate with PNGase F (removing oligosaccharides from proteins) prior to immunoblotting resulted in a faster electrophoretic migration of Rab7b in SDS/PAGE (Fig. 4 lane 2) in comparison with the untreated sample (Fig. 4 lane 1). No effect of PNGase treatment on electrophoretic mobility of Rab7a was noticed (not shown). Immunoprecipitated Rab7b but not Rab7a was found to bind peroxidaselabeled Concanavalin A in blot overlay (Fig. 5). Lectin Con A binds to both mannose and glucose and the result of the overlay test strongly suggests glycosylation of Rab7b.

\section{Immunolocalization studies by confocal, STED and electron microscopy}

Confocal laser microscopy revealed most of Rab7a labeling on phagosomes (Fig. 6A), which was especially evident at the higher magnification (Fig. 6B). Rab7b was localized mostly to the oral apparatus (Fig. 6A, arrows). In order to map Rab7b more precisely STED confocal laser microscope was used for visualization of the ciliate

Table 2. Comparison of the Rab-specific motifs in Paramecium octaurelia Rab7 isotypes identified by proteomic analysis with the respective Metazoan motifs*.

\begin{tabular}{lll}
\hline Motif & Paramecium octaurelia & Metazoa \\
\hline RabF1 & ${ }^{41}$ VGADF $^{45}$ & ${ }^{41}$ GADF $^{45}$ \\
RabF3 & ${ }^{69}$ RFQSLG74 $^{74}$ & ${ }^{69}$ RFQSLG $^{74}$ \\
RabF4 & ${ }^{77}$ FYRGA $^{81}$ & ${ }^{77}$ FYRGA $^{81}$ \\
RabF5 & ${ }^{86}$ LVYDIT $^{91}$ & ${ }^{86}$ LVYDVT $^{91}$ \\
RabSF2 & ${ }^{23}{ }^{2}$ LMNQYVNARFTQQYRA $^{39}$ & ${ }^{23}$ SLMNQYVNKKFSNQYKA ${ }^{39}$ \\
RabSF4 & ${ }^{176 S Q E K D E E I F F P T T ~}{ }^{188}$ & ${ }^{175}$ AQESEVELYNEFP187 \\
\hline
\end{tabular}

*Metazoa motifs as in Mackiewicz \& Wyroba (2009). oral apparatus by double immunolabeling with $\alpha$-tubulin (Fig. 6C-F). Rab7b association with tubular structures was visualized at different confocal sections and at the higher resolution (Fig. 6D, F), mapping partially to the region of basal bodies arranged into the rows called peniculus and quadrulus (Clerot et al., 2001). No Rab7b labeling on phagosomes containing latex beads was observed (Fig. 6A, C-F). Immunogold detection in electron microscopy revealed Rab7a at membranes of phagosomes containing latex beads (Fig. 7A, arrows). No or single gold particles decorating Rab7b were detected in phagosome vicinity (Fig. 7A, arrowhead). In the doubleimmunogold experiments with $\alpha$-tubulin, Rab7b was detected in association with the bundles of microtubules in the oral apparatus region (Fig. 7B, C), consistently with the pattern shown in Figures 6A, C-F.

\section{Expression of Rab 7 isotypes}

Absolute real-time PCR analysis revealed that the expression level of $r a b 7 a$ is 2.6 times higher than $r a b 7 b$ in non-stimulated cells. In order to follow changes in expression pattern of Rab7 isotypes during phagocytosis, relative real-time PCR and quantitative immunoblotting were performed. A significant 2.4-fold increase in the level of rab7a transcript was observed after $25 \mathrm{~min}$ of phagocytosis - that corresponds to the stage of the formation of phagolysosomes (Allen \& Fok, 2000) as compared to non-phagocyting cells, contrary to that of rab7b mRNA elevated only by $43 \%$ (Fig. 8). Taken together, these results indicate that during phagocytosis expression of rab7a is almost 5-times higher than that of rab7b. Expression of Rab7 proteins reflected the genes' profile described above: a gradual increase in Rab7a level up to 2.16-fold after $25 \mathrm{~min}$ of latex uptake was observed by quantitative Western blotting while expression of Rab7b was elevated by $55 \%$ in comparison with non-phagocyting cells (Fig. 8).

\section{RNAi of rab7 genes and its phenotypic effects}

The expression of genes encoding Rab7 proteins was silenced in order to determine the physiological function of these GTPases in Paramecium octaurelia. RNAi efficiency on the mRNA and protein levels was controlled by RT-PCR and quantitative Western blot to observe (i) knockdown of the target gene, (ii) paralogue knockdown and (iii) knockdown specificity. In each series RNAi evoked a decrease 



\section{Latex beads}

B
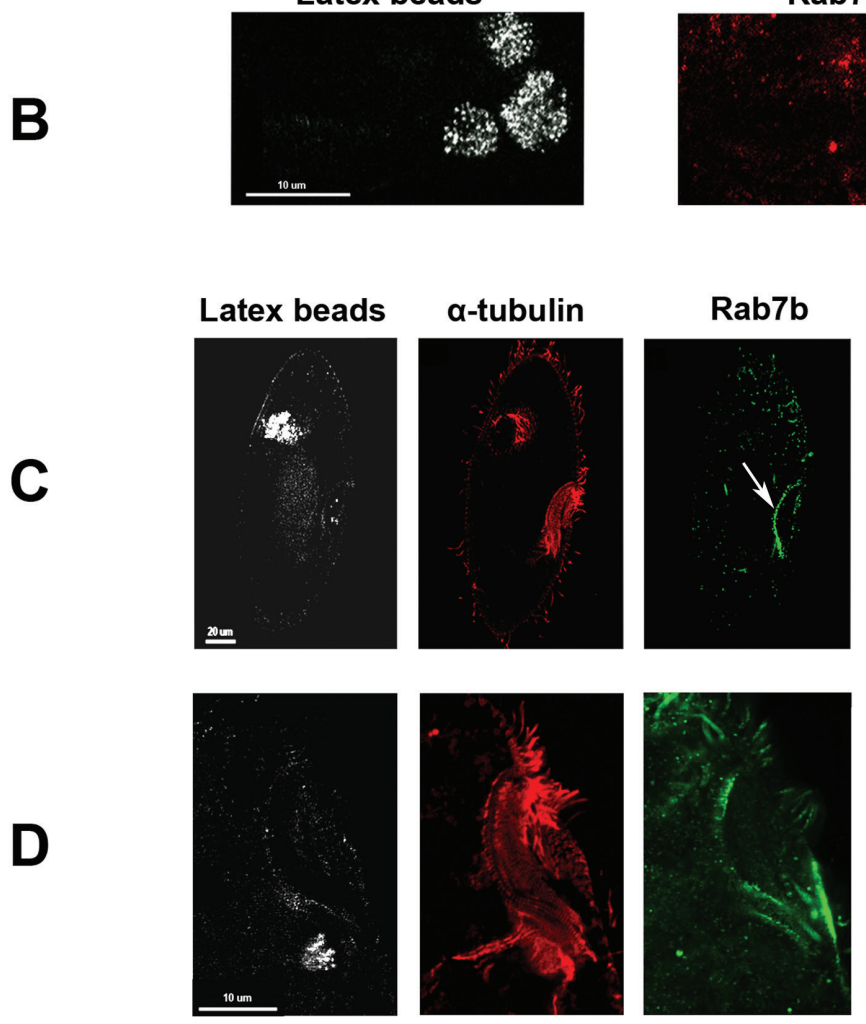

D
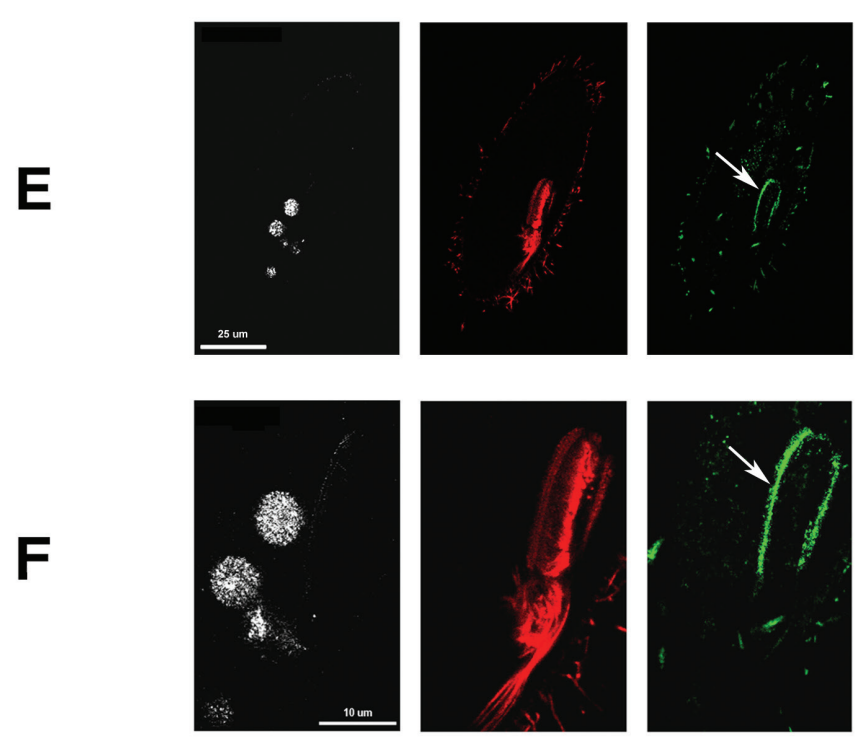

\section{Rab7a}

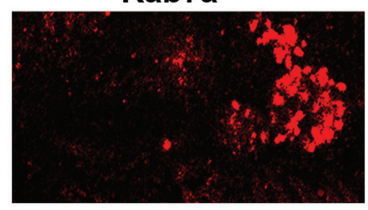

\section{Merge}
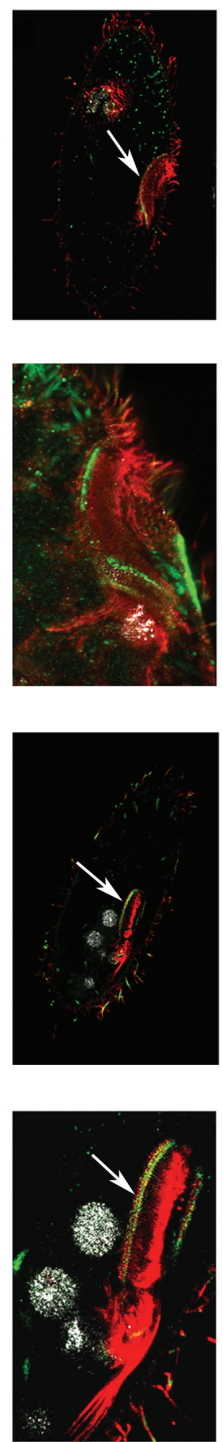

Figure 6. Intracellular mapping of $P$. octaurelia Rab7 isotypes in confocal/STED microscopy.

Confocal and STED laser microscopy were used to follow the localization of Rab7 isotypes within the cell during latex internalization. Dual fluorochrome immunolabeling reaction was performed using anti-Rab7a (A, B), anti-Rab7b (A, C-F) or anti-a-tubulin antibodies (CF), respectively, and followed by detection with CY5 (Rab7a - red, panel A and B), FITC (Rab7b - green, panels A, C-F). Tubulin (C-F) was visualized with ATTO647N (red) in STED confocal mode. Latex beads in phagosomes visible as white particles in a dark field. Panel $\mathrm{F}$ is the higher magnification of panel E. Arrows indicate localization of Rab7b to the oral apparatus. 

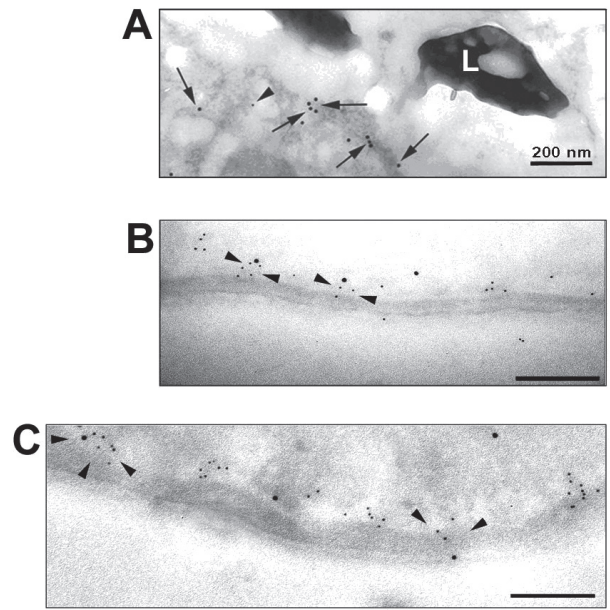

Figure 7. Ultrastructural localization of Rab7a and Rab7b in P. octaurelia.

Double immunogold labeling was performed as described in Materials and Methods. (A) Electron microscopy analysis revealed presence of Rab7a (shown with $12 \mathrm{~nm}$ gold particles, arrows) at the membranes of the phagosomes containing the internalized latex beads (L). None or trace labeling of Rab7b ( $5 \mathrm{~nm}$ gold, arrowhead) in this compartment was visible. Rab7b was mainly detected in association with the microtubular structures (B, C) revealed by labeling with anti-a-tubulin Ab (10 nm gold). Scale bar: $200 \mathrm{~nm}$.

in rab7a mRNA level by $79 \%$ and rab7b by $58 \%$ (Fig. $9 \mathrm{~A}, \mathrm{~B})$ that was also reflected at the protein level being reduced by $80 \%$ and $60 \%$, respectively (Fig. 9C, D). No significant co-silencing of the respective paralogous gene was observed (Fig. 9B, D). Silencing of rab7a gene evoked a strong phenotypic effect and diminished the average number of phagosomes by $70 \%$ as examined by internalization of latex, whereas acidification of the few phagosomes formed was impaired (Fig. 10B) in comparison with the control (Fig. 10A) when uptake of Congo-Red-stained yeast (15 min) was

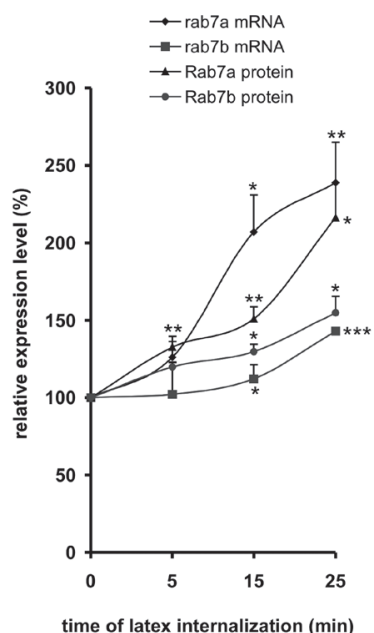

Figure 8. Differential expression of $r a b 7$ genes and their protein products during phagocytosis of latex beads analyzed by Realtime PCR and quantitative immunoblotting.

Relative quantity of $r a b 7 a$ and $r a b 7 b$ gene expression was estimated using the $\triangle \Delta C_{T}$ method. The graph shows the mean value of rab7 transcripts levels during phagocytosis normalized to GAPDH and related to the expression of rab7a or rab7b in control cells that was set to $100 \% . n \geq 3$. Quantitative Western blot with specific antipeptide antibodies against Rab7a or Rab7b was used to determine changes in protein expression. GAPDH was used as a control of equal loading. $n \geq 3$. Statistical significance was evaluated applying Student's $t$-test for independent variables: ${ }^{*} P<0.05$, ${ }^{* *} P<0.01,{ }^{* * *} P<0.001$ with respect to control cells. monitored. Congo Red changes its color from red $(\geq$ $\mathrm{pH} 5.2)$ to blue $(\mathrm{pH} \leq 3)$ and was used as a $\mathrm{pH}$ indicator. RNAi of rab7b gene evoked a $12 \%$ decrease in formation of phagosomes and did not significantly change their acidification (Fig. 10C). Double silencing experiments resulted in a significant decrease of both the protein products: by $70.5 \%$ and $58 \%$ for Rab7a and Rab7b, respectively, i.e., almost identical to the effect of RNAi of each single gene. The phenotype of such cells was similar to that of the rab7a-silenced ciliates: inhibition of phagosome formation and their acidification (not shown).

The inhibition of phagosome acidification upon silencing of rab7a may be due to the lack of vacuolar type $\mathrm{H}+$-ATPase (V-ATPase) recruitment. Indeed, such an effect was observed at the ultrastructural level. Control cells show colocalization of Rab7a and V-ATPase in the vicinity of the membrane surrounding phagolysosomes containing latex beads (Fig. 11A). Upon RNAi of rab7a gene the recruitment of V-ATPase to the phagolysosomal compartment was impaired and only single gold particles labeling the both proteins were visible (Fig. 11B). Silencing of rab7b gene did not affect recruitment of V-ATPase (Fig. 11C, D) and Rab7a (Fig. 11C) to the phagolysosomes whereas it almost eliminated recruitment of Rab7b (Fig. 11D). Moreover, these results indicate that silencing of rab7b gene did not induce co-silencing of rab7a.

\section{DISCUSSION}

Intracellular membrane trafficking is regulated by Rab proteins that are the largest family of small monomeric GTPases in eukaryotic cells (Zerial \& Mc Bride, 2001; Stenmark, 2009). Each of these GTPases functions at one or more specific steps of endocytosis by assembling the general tethering/docking/fusion machinery (Stenmark \& Olkkonen, 2001; Pfeffer \& Aivazian, 2004; Bucci \& Chiarello, 2006).

The aim of this study was to find out what is the function, expression and localization of P. octaurelia Rab7 GTPases encoded by genes exhibiting 97.6\% identity. Our results indicate that they display differential expression pattern and are targeted to distinct intracellular locations, which has not previously been shown for single free-living eukaryotic cells. Both these proteins exhibit conserved Rab-specific motifs, identical prenylation motifs and eight phosphorylated residues as confirmed by mass spectrometry.

Biochemical tests suggested that Rab7b may be glycosylated. In silico analysis of potential glycosylation sites (Julenius et al., 2005) indicated 23 O-glycosylation sites shared by both Rab7 proteins and three ones unique: two of them in Rab7b (Ser ${ }^{140}$ and $\mathrm{Thr}^{200}$ ) and only one in Rab7a at Ser ${ }^{195}$. Moreover, $\mathrm{Thr}^{200}$ in Rab7b is in the hypervariable region that participates in determination of specificity of Rab7 interactions with membranes and its localization within the cell (Ali et al., 2004). No differences were found in the six potential $N$-glycosylation sites. Glycosylation is well known to modulate proteinprotein interactions and to increase the apparent molecular weight of proteins observed in electrophoresis (Lewis et al., 1985; Price et al., 1995, Yaqoob et al., 1995). Therefore, it seems reasonable to suggest that the lower electrophoretic mobility of Rab7b in SDS/PAGE in comparison with Rab7a may be due to glycosylation and this will be further studied using recombinant proteins 
A
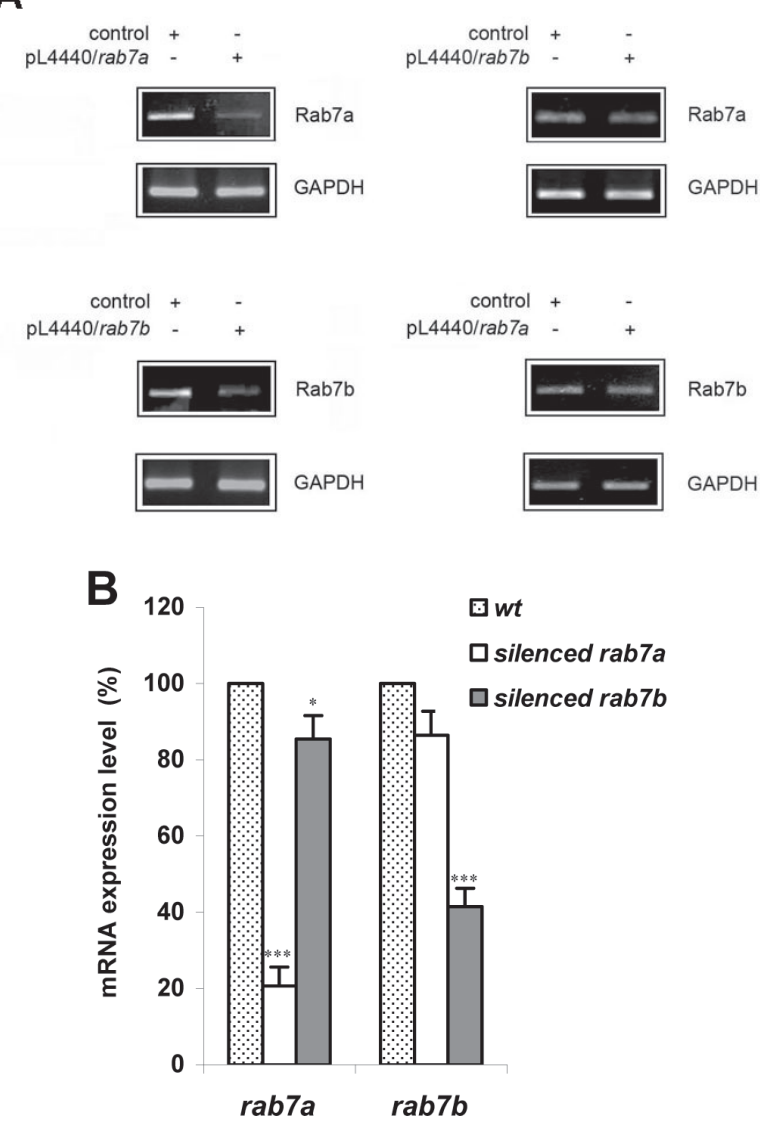

C

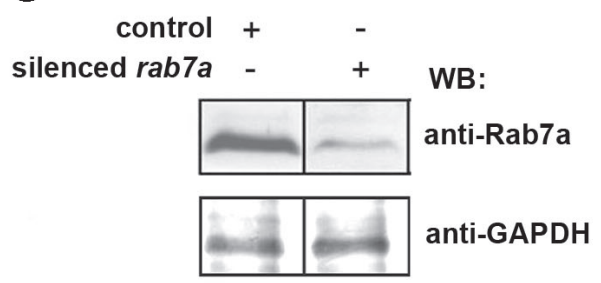

and site-directed mutagenesis. A Cytosolic glycosylation pathway is known for Paramecium parafusin (Subramanian \& Satir, 1992) and its homologue in Toxoplasma gondii (Matthiesen et al., 2001). Parafusin is a member of phosphoglucomutase (PGM) superfamily (Subramanian et al., 1994) with no PGM enzymatic activity (Andersen et al., 1994) and is reversibly dephosphoglucosylated upon $\mathrm{Ca}^{2+-}$ dependent exocytosis. This process does not occur in the exocytosis mutant nd9 (Subramanian \& Satir, 1992). Knockdown of parafusin inhibits secretion (Liu et al., 2011).

The post-translational modification of Rab7b may also contribute to its acquiring a new function as a putative component interacting with bundles of microtubules and structures supporting the oral apparatus. According to Amoutzias (2010), changes in post-translational modification represent rapid routes to the sub- and neofunctionalization of duplicated genes and thereby promote the retention of duplicate pairs. In the Paramecium oral apparatus dynamic fusions/remodelings of membrane occur during phagocytosis (Allen, 1974), and the presence of tubulin (Cohen \& Beisson, 1988), its polyglycylated form (Iftode et al., 2000), some isoforms of actin (Plattner, 2010), centrin (Klotz et al., 1997), SNARE proteins

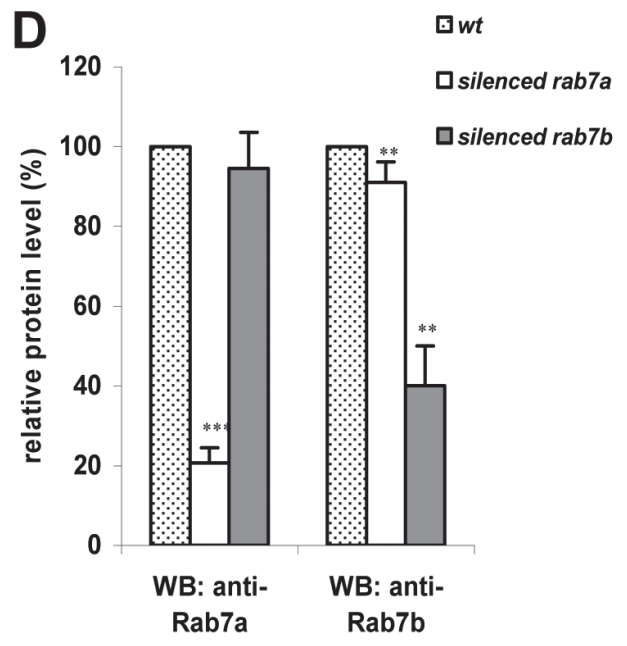

Figure 9. Decrease of rab7a and rab7b expression and their protein products upon gene silencing.

RT-PCR was used to determine relative expression of both genes that was normalized to that of gapdh in each sample after gene silencing. (A) Representative gel of RT-PCR products. (B) Changes in transcript level after RNAi of rab7a or rab7b. (C) Effect of gene silencing on protein level - representative Western blot. (D) Protein expression was evaluated by Western immunoblotting with specific antipeptide Abs to Rab7a and Rab7b. GAPDH was used as a control of equal loading. No significant effect of co-silencing was observed at the transcript and protein level. Data were obtained from three separate experiments (mean values \pm S.E.M.) and normalized to $100 \%$ in the control cells. Statistical significance was evaluated applying Student's $t$-test for independent variables: ${ }^{*} P<0.05$, ${ }^{* *} P<0.01$, ${ }^{* *} P<0.001$ with respect to the control.

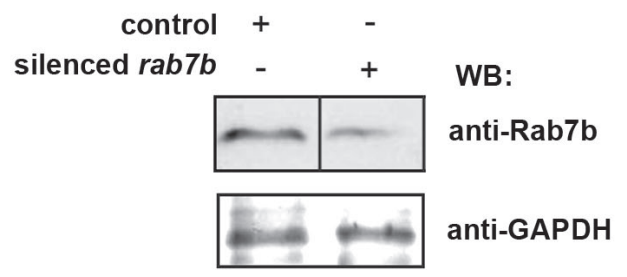

(Kissmehl et al., 2007) and epiplasmin 1 (Damaj et al., 2009) as well as filaments related to tetrins (Clerot et al., 2001) have been reported.

Image analyses showed the presence of Rab7a within the phagosomal compartment in accordance with our previous results with the use of anti-human Rab7b antibody that was not discriminating Paramecium Rab7 isotypes (Surmacz et al., 2003; Wyroba et al., 2007). An essential role of Rab7a in phagosome maturation was further supported by its enhanced expression during this process. Upon silencing of Rab7a, formation of phagosome was inhibited by $70 \%$ and their acidification was impaired due to the lack of V-ATPase recruitment. Interestingly, analysis of the phagosomal proteome of Dictyostelium discoideum has revealed genes encoding three V-ATPase subunits and Rab7 (Sillo et al., 2008). Silencing of V-ATPase in Paramecium tetraurelia (Wassmer et al., 2009) and altered expression of a $100-\mathrm{kDa}$ subunit in Dictyostelium discoideum (Liu et al., 2002) impaired phagosome acidification leading to decreased phagocyting activity. The single Rab7 protein present in Tetrabymena thermophila has been mapped to phagosomes and lysosomes (Bright et al., 2010) but no data are available on knock-out effects. Recently, Kashiwazaki et al. (2009) have identified 
A

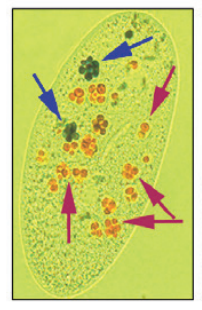

B

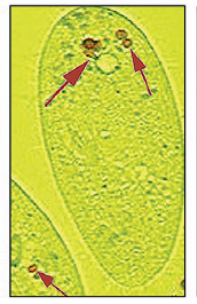

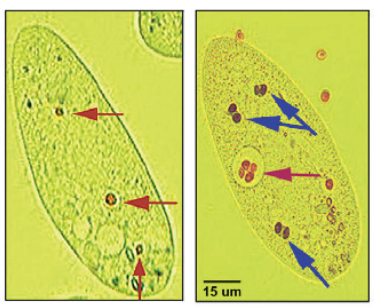

Figure 10. Impairment of phagosome acidification upon silencing of rab7a gene.

Congo-stained yeast uptake. Representative images of control (A), rab7a-silenced (B) or rab7b-silenced (C) cells internalizing yeasts for $15 \mathrm{~min}$. No acidification of scare phagosomes was observed upon RNAi of rab7a gene (B). The red color of Congo-Red-stained yeast (red arrows) indicates that their $\mathrm{pH}$ is above 5, while the $\mathrm{pH}$ of blue colored yeast (blue arrows) is below 3 .

two Schizosaccharomyces pombe Rab7 homologs that act antagonistically in regulating vacuolar morphology. Analysis of a chimeric Ypt7/Ypt71 protein showed that Rab7directed vacuole dynamics, fusion versus fission, largely depends on the medial region of the protein, including a part of RabSF3/ 3 3-L7. In P. octaurelia this motif is identical in both Rab7 proteins but slightly differs from that present in Ras protein.

Two genes encoding Rab7 are known in the human: one of the encoded Rab7 isotypes is the localized in late endosomes and lysosomes (Bucci et al., 2000), whereas the recently identified Rab7b is involved in monocytic


Figure 11. Effect of silencing of rab7 genes on recruitment of $\mathrm{V}$ ATPase to the phagolysosomal compartment.

Control cells (A) show colocalization of Rab7a (black arrows) and V-ATPase (white arrowheads) at the vicinity of phagosomal membrane surrounding latex beads (L). Upon RNAi of rab7a gene the uptake of latex was blocked and none or only single gold particles labeling both the proteins were visible (B). Silencing of rab7b gene did not impair V-ATPase and Rab7a recruitment to the phagolysosomes (C) whereas almost eliminated Rab7b (D) as shown with black arrowhead. Double-immunogold labeling performed as described in Materials and Methods. Control cells (A) and cells after silencing of rab7a gene (B) were labeled with: anti-Rab7a and anti-V-ATPase followed by the secondary antibody conjugated with $12 \mathrm{~nm}$ or $5 \mathrm{~nm}$ gold particles, respectively. Cells after silencing of $r a b 7 b$ gene were labeled either with anti-Rab7a and anti-V-ATPase and subsequently with the secondary antibody conjugated with $12 \mathrm{~nm}$ or $5 \mathrm{~nm}$ gold particles, respectively (C) or with anti-Rab7b and anti-V-ATPase followed by the secondary antibody conjugated with $10 \mathrm{~nm}$ or $5 \mathrm{~nm}$ gold particles (D). SL secondary lysosome. Scale bar: $200 \mathrm{~nm}$. differentiation and is essential for retrograde transport from endosomes to the TGN (Progida et al., 2010). The parasitic protist Entamoeba histolytica has at least nine isotypes of Rab7 (Saito-Nakano et al., 2005) out of which five have been identified by proteomic analysis in latex bead-containing phagosomes (Okada et al., 2005).

In Paramecium at least three whole-genome duplications (WGD) occurred: the old one before the divergence of Paramecium and Tetrabymena, and the recent before the divergence of $P$. tetraurelia and $P$. octaurelia (Aury et al., 2006). The Paramecium genome is a useful model to study - protein products of duplicated genes acquire new function/localization in the cell during evolution, as has been shown in $P$. tetraurelia for actin (Sehring et al., 2007) and syntaxin (Plattner, 2010). The two Rab7 isotypes described here are a next example of this phenomenon and the first for Rab GTPases in a non-parasite single-celled Eukaryote. Saito-Nakano et al. (2010) reported in Paramecium tetraurelia 229 Rab genes based on $>40 \%$ amino acid identity to Rab from other organisms with three genes belonging to the Rab7 subfamily. We hypothesize that the presence of only two Rab7 proteins in $P$. octaurelia - that emerged in the last WGD - is in accordance with data (Axelsen et al., 2007) that successive removal of paralogous genes took place since they did not have enough time to significantly change their roles and, moreover, supporting the idea of asymmetric evolution of duplicate genes (VanderSluis et al., 2010).

Targeting of Rab proteins to distinct locations is a subject of dispute. According to Itzen and Goody (2010) a hydrophobic amino acid triad occurring in the majority of Rab proteins that includes phenylalanine of RabF1 motif is involved in Rab-effector interactions. This triad: $\mathrm{F}^{45}, \mathrm{~W}^{62}, \mathrm{Y}^{78}$ (Brighouse et al., 2010) is identical in the both Rab7 isotypes of $P$. octaurelia.

Different models have been proposed to explain specificity of Rabs' localization and function. One of them postulates five subfamily motifs as determinants of functional diversity while others suggest switch/interswitch regions or variability in the protein core to be the most important for specificity (Lee et al., 2009). Hybrid experiments swapping the hypervariable domain between different Rab proteins resulted in their mislocalization only in some cases (Ali \& Seabra, 2005), indicating that Rab recruitment is complex (Ali et al., 2004) and Rab regulators may be also involved in this process (Stenmark, 2009).

As concerns the two Rab7 GTPases studied here, the only other difference between these sequences - besides the divergent $\mathrm{C}$-termini - is the substitution of alanine at position 140 (in the region between G2 and G3) in Rab7a with serine in Rab7b. Alanine was found to be $100 \%$ conserved among Rab7 proteins from different species in an alignment according to BLOSUM 62 and is located in the region of $\alpha$-helix with the highest frequency of secondary structure elements (Mackiewicz \& Wyroba, 2009). This substitution changed the non-polar and helix-favoring Ala into the polar and helix-disfavoring Ser (Zimmerman et al., 1968), which could contribute both to an alteration of Rab7b interactions and also introduced a reactive serine hydroxyl group. Interestingly, the Paramecium tetraurelia database contains a PtRab_B30 sequence as a homologue of Rab7 that displays also serine in this position but no data are available on this protein. It cannot be excluded that serine at this position in Rab7 may be a Paramecium-specific feature, since the typical alanine is present in Tetrabymena thermophila Rab7 (Eisen et al., 2006). 
Taking together, the presented results show that $P$. octaurelia Rab7a involved in phagosome maturation is the protein fulfilling the role of the Rab7 GTPases in higher eukaryotes, whereas Rab7b acquired a new function.

\section{Acknowledgements}

We are grateful to Prof. J. Silberring and Dr. P Suder (Department of Biochemistry and Neurobiology, Faculty of Materials Science and Ceramics, AGH University of Science and Technology, Kraków) for valuable discussions on mass spectrometry. E. coli strain HT115 was obtained from Caenorbabditis Genetics Center funded by the NIH National Center for Research Resources.

This work was supported by statutory funds to the Nencki Institute of Experimental Biology and grant N N303 615038 from the Ministry of Science and Higher Education.

\section{REFERENCES}

Ali BR, Seabra MC (2005) Targeting of Rab GTPases to cellular membranes. Biochem Soc Trans 33: 652-656.

Ali BR, Wasmeier C, Lamoreux L, Strom M, Seabra MC (2004) Multiple regions contribute to membrane targeting of Rab GTPases. J Cell Sci 117: 6401-6412.

Allen RD (1974) Food vacuole membrane growth with microtubule-associated membrane transport in Paramecium. I Cell Biol 63: 904-922.

Allen RD, Fok AK (2000) Membrane trafficking and processing in Paramecium. Int Rev Cytol 198: 277-318.

Amoutzias GD, He Y, Gordon J, Mossialos D, Oliver SG, Van de Peer Y (2010) Posttranslational regulation impacts the fate of duplicated genes. Proc Natl Acad Sci USA 107: 2967-2971.

Andersen, AP, Wyroba E, Reichman M, Zhao H, and Satir BH (1994) The activity of parafusin is distinct from that of phosphoglucomutase in the unicellular eukaryote Paramecium. Biochem Biophys Res Commun 200: 1353-1358.

Aury JM, Jaillon O, Duret L, Noel B, Jubin C, Porcel BM, Ségurens B, Daubin V, Anthouard V, Aiach N, Arnaiz O, Billaut A, Beisson J, Blanc I, Bouhouche K, Câmara F, Duharcourt S, Guigo R, Gogendeau D, Katinka M, Keller AM, Kissmehl R, Klotz C, Koll F, Le Mouël A, Lepère G, Malinsky S, Nowacki M, Nowak JK, Plattner H, Poulain J, Ruiz F, Serrano V, Zagulski M, Dessen P, Bétermier M, Weissenbach J, Scarpelli C, Schächter V, Sperling L, Meyer E, Cohen J, Wincker P (2006) Global trends of whole-genome duplications revealed by the ciliate Paramecium tetraurelia. Nature 444: 171-178.

Axelsen BJ, Yan KK, Maslov S (2007) Parameters of proteome evolution from histograms of amino-acid sequence identities of paralogous proteins. Biol Direct 2: 32.

Bierczynska-Krzysik A, Bonar E, Drabik A, Noga M, Suder P, Dylag T, Dubin A, Kotlinska J, Silberring J (2006) Rat brain proteome in morphine dependence. Neurochem Int 49: 401-406.

Brighouse A, Dacks JB, Field MC (2010) Rab protein evolution and the history of the eukaryotic endomembrane system. Cell Mol Life Sci 67: 3449-3465.

Bright LJ, Kambesis N, Nelson SB, Leong B, Turkewitz AP (2010) Comprehensive analysis reveals dynamic and evolutionary plasticity of Rab GTPases and membrane traffic in Tetrabymena thermophila. PLoS Genet 14: e1001155.

Bucci C, Chiariello M (2006) Signal transduction gRABs attention. Cell Signal 18: 1-8.

Bucci C, Thomsen P, Nicoziani P, McCarthy J, van Deurs B (2000) Rab7: a key to lysosome biogenesis. Mol Biol Cell 11: 467-480.

Clerot J-C, Iftode F, Budin K, Jeanmaire-Wolf R, Coffe G, FleuryAubusson A (2001) Fine oral filaments in Paramecium: a biochemical and immunological analysis. J Eukaryot Microbiol 48: 234-245.

Cohen J, Beisson J (1988) The Cytoskeleton. In Paramecium. Görtz HD, ed, pp 363-392. Springer-Verlag, Berlin.

Dacks JB, Poon PP, Field MC (2008) Phylogeny of endocytic components yields insight into the process of nonendosymbiotic organelle evolution. Proc Natl Acad Sci USA 105: 588-593.

Damaj R, Pomel S, Bricheux G, Coffe G, Viguès B, Ravet V, Bouchard P (2009) Cross-study analysis of genomic data defines the ciliate multigenic epiplasmin family: strategies for functional analysis in Paramecium tetraurelia. BMC Evol Biol 9: 125.

Eisen JA, Coyne RS, Wu M, Wu D, Thiagarajan M, Wortman JR, Badger JH, Ren Q, Amedeo P, Jones KM, Tallon LJ, Delcher AL, Salzberg SL, Silva JC, Haas BJ, Majoros WH, Farzad M, Carlton
JM, Smith RK Jr, Garg J, Pearlman RE, Karrer KM, Sun L, Manning G, Elde NC, Turkewitz AP, Asai DJ, Wilkes DE, Wang Y, Cai H, Collins K, Stewart BA, Lee SR, Wilamowska K, Weinberg Z, Ruzzo WL, Wloga D, Gaertig J, Frankel J, Tsao CC, Gorovsky MA, Keeling PJ, Waller RF, Patron NJ, Cherry JM, Stover NA, Krieger CJ, del Toro C, Ryder HF, Williamson SC, Barbeau RA, Hamilton EP, Orias E (2006) Macronuclear genome sequence of the ciliate Tetrabymena thermophila, a model eukaryote. PLoS Biol 4: e286.

Elias M (2010) Patterns and processes in the evolution of the eukaryotic endomembrane system. Mol Membr Biol 27: 469-489.

Galvani A, Sperling L (2002) RNA interference by feeding in Paramecium. Trends Genet 18: 11-12.

Gunther GR, Wang JL, Yahara I, Cunningham BA, Edelman GM (1973) Concanavalin A derivatives with altered biological activities. Proc Natl Acad Sci USA 70: 1012-1016.

Ho MN, Hirata R, Umemoto N, Ohya Y, Takatsuki A, Stevens TH, Anraku Y (1993) VMA13 encodes a $54-\mathrm{kD}$ a vacuolar $\mathrm{H}(+)$-ATPase subunit required for activity but not assembly of the enzyme complex in Saccharomyces cerevisiae. J Biol Chem 268: 221-227.

Iftode F, Clérot JC, Levilliers N, Bré MH (2000) Tubulin polyglycylation: a morphogenetic marker in ciliates. Biol Cell 92: 615-628.

Itzen A, Goody RS (2010) GTPases involved in vesicular trafficking: structures and mechanisms. Semin Cell Dev Biol 22: 48-56.

Jékely G (2007) Origin of eukaryotic endomembranes: a critical evaluation of different model scenarios. Adv Exp Med Biol 607: 38-51.

Julenius K, Mølgaard A, Gupta R, Brunak S (2005) Prediction, conservation analysis and structural characterization of mammalian mucintype O-glycosylation sites. Glycobiology 15: 153-164.

Kashiwazaki J, Iwaki T, Takegawa K, Shimoda C, Nakamura T (2009) Two fission yeast Rab7 homologs, Ypt7 and Ypt71, play antagonistic roles in the regulation of vacuolar morphology. Traffic 10: 912-924.

Kinchen JM, Ravichandran KS (2008) Phagosome maturation: going through the acid test. Nat Rev Mol Cell Biol 9: 781-795.

Kissmehl R, Schilde C, Wassmer T, Danzer C, Nuehse K, Lutter K, Plattner H (2007) Molecular identification of 26 syntaxin genes and their assignment to the different trafficking pathways in Paramecium. Traffic 8: 523-542.

Klotz C, Garreau de Loubresse N, Ruiz F, Beisson J (1997) Genetic evidence for a role of centrin-associated proteins in the organization and dynamics of the infraciliary lattice in Paramecium. Cell Motil Cytoskeleton 38: 172-86.

Lee MT, Mishra A, Lambright DG (2009) Structural mechanisms for regulation of membrane traffic by rab GTPases. Traffic 10: 13771389.

Lewis UJ, Singh RNP, Sinha YN, Vanderlaan WP (1985) Glycosylated human prolactin. Endocrinology 116: 359-363.

Liu T, Mirschberger C, Chooback L, Arana Q, Dal Sacco Z, MacWilliams H, Clarke M (2002) Altered expression of the $100 \mathrm{kDa}$ subunit of the Dictyostelium vacuolar proton pump impairs enzyme assembly, endocytic function and cytosolic $\mathrm{pH}$ regulation. J Cell Sci 115: 1907-1918.

Liu L, Wyroba E, Satir BH (2011) RNAi Knockdown of Parafusin Inhibits The Secretory Pathway. Eur J Cell Biol 90: 844-853.

Mackiewicz P, Wyroba E (2009) Phylogeny and evolution of Rab7 and Rab9 proteins. BMC Evol Biol 9: 101.

Matthiesen SH, Shenoy SM, Kim K, Singer RH, Satir BH (2001) A parafusin-related Toxoplasma protein in $\mathrm{Ca}^{2+}$ regulated secretory organelles. Eur J Cell Biol 80: 775-783.

Noga MT, Lewandowski JJ, Suder P, Silberring J (2005) An enhanced method for peptides sequencing by N-terminal derivatization and MS. Proteomics 5: 4367-4375.

Okada M, Huston CD, Mann BJ, Petri WA Jr, Kita K, Nozaki T (2005) Proteomic analysis of phagocytosis in the enteric protozoan parasite Entamoeba histolytica. Eukaryot Cell 4: 827-831.

Parra KJ, Keenan KL, Kane PM (2000) The H subunit (Vma13p) of the yeast ATPase inhibits the ATPase activity of cytosolic V1 complexes. J Biol Chem 275: 21761-21767.

Pfeffer SR, Aivazian D (2004) Targeting Rab GTPases to distinct membrane compartments. Nat Rev Mol Cell Biol 5: 886-896.

Plattner H (2010) Membrane trafficking in protozoa:SNARE proteins, $\mathrm{H}+$-ATPase, actin, and other key players in ciliates. Int Rev Cell Mol Biol 280: 179-184.

Price AE, Logvinenko KB, Higgins EA, Cole ES, Richards S (1995) Studies on the microheterogeneity and in vitro activity of glycosylated and nonglycosylated recombinant human prolactin separated using a novel purification process. Endocrinology 136: 4827-4833.

Progida C, Cogli L, Piro F, De Luca A, Bakke O, Bucci C (2010) Rab7b controls trafficking from endosomes to the TGN. J Cell Sci 123: $1480-1491$.

Rupper A, Grove B, Cardelli J (2001) Rab7 regulates phagosome maturation in Dictyostelium. J Cell Sci 114: 2449-2460.

Saito-Nakano Y, Lotus BJ, Hall N, Nozaki T (2005) The diversity of Rab GTPases in Entamoeba bistolytica. Exp Parasitol 110: 244-252.

Saito-Nakano Y, Nakahara T, Nakano K, Nozaki T, Numata O (2010) Marked amplification and diversification of products of ras genes 
from rat brain, Rab GTPases, in the ciliates Tetrabymena thermophila and Paramecium tetraurelia. J Eukaryot Microbiol 57: $389-399$.

Satir BH, Srisomsap C, Reichman M, Marchase RB (1990) Parafusin, an exocytic-sensitive phosphoprotein, is the primary acceptor for the glucosylphosphotransferase in Paramecium tetraurelia and rat liver. J Cell Biol 111: 901-917.

Sehring IM, Reiner C, Mansfeld J, Plattner H, Kissmehl R (2007) A broad spectrum of actin paralogs in Paramecium tetraurelia cells display differential localization and function. J Cell Sci 120: 177-190.

Sillo A, Bloomfield G, Balest A, Balbo A, Pergolizzi B, Peracino B, Skelton J, Ivens A, Bozzaro S (2008) Genome-wide transcriptional changes induced by phagocytosis or growth on bacteria in Dictyostelium. BMC Genomics 9: 291.

Soldo AT, Godoy GA, van Wagtendonk WJ (1966) Growth of particle-bearing and particle-free Paramecium aurelia in axenic culture. $J$ Protozool 13: 492-497.

Stenmark H (2009) Rab GTPases as coordinators of vesicle traffic. Nat Rev Mol Cell Biol 10: 513-525.

Stenmark H, Olkkonen VM (2001) The Rab GTPase family. Genome Biol 2: reviews 3007.1-3007.7

Subramanian SV, Satir BH (1992) Carbohydrate cycling in signal transduction: parafusin, a phosphoglycoprotein and possible $\mathrm{Ca}^{2+}$-dependent transducer molecule in exocytosis in Paramecium. Proc Natl Acad Sci USA 89: 11297-11301.

Subramanian SV, Wyroba E, Andersen AP, Satir BH (1994) Cloning and sequencing of parafusin, a calcium-dependent exocytosis-related phosphoglycoprotein. Proc Natl Acad Sci USA 91: 9832-9836.

Surmacz L, Wiejak J, Wyroba E (2003) Evolutionary conservancy of the endocytic machinery in the unicellular eukaryote Paramecium. Biol Cell 95: 69-74.

Surmacz L, Wiejak J, Wyroba E (2006) Cloning of two genes encoding Rab7 in Paramecium. Acta Biochim Pol 53: 149-156.
Timmons L, Fire A (1998) Specific interference by ingested dsRNA. Nature 395: 854.

VanderSluis B, Bellay J, Musso G, Costanzo M, Papp B, Vizeacoumar FJ, Baryshnikova A, Andrews B, Boone C, Myers CL' (2010) Genetic interactions reveal the evolutionary trajectories of duplicate genes. Mol Syst Biol 16: 429.

Vanlandingham PA, Ceresa BP (2009) Rab7 regulates late endocytic trafficking downstream of multivesicular body biogenesis and cargo sequestration. J Biol Chem 284: 12110-12124.

Vieira OV, Botelho RJ, Grinstein S (2002) Phagosome maturation: aging gracefully. Biochem I 366: 689-704.

Wassmer T, Sehring IM, Kissmehl R, Plattner H (2009) The V-ATPase In Paramecium: functional specialization by multiple gene isoforms. Pflugers Arch 457: 599-607.

Wiejak J, Surmacz L, Wyroba E (2004) Dynamin- and clathrin-dependent endocytic pathway in unicellular eukaryote Paramecium. Biochem Cell Biol 82: 547-558.

Winer J, Jung CK, Shackel I, Williams PM (1999) Development and validation of real-time quantitative reverse transcriptase-polymerase chain reaction for monitoring gene expression in cardiac myocytes in vitro. Anal Biochem 270: 41-49.

Wyroba E, Surmacz L, Osinska M, Wiejak J (2007) Phagosome maturation in unicellular eukaryote Paramecium: the presence of RILP, Rab7 and LAMP-2 homologues. Eur J Histochem 51: 163-172.

Yaqoob M, Snell CR, Burgess GM (1995) Carbohydrate analysis of the B2 bradykinin receptor from rat uterus. J Neurochem 65: 1290-1296.

Zerial M, McBride H (2001) Rab proteins as membrane organizers. Nat Rev Mol Cell Biol 2: 107-117.

Zimmerman JM, Eliezer, N, Simha R (1968) The characterization of amino acid sequences in proteins by statistical methods. J Theor Biol 21: $170-201$. 